\title{
Telegraph communication networks used by the Japanese pharmaceutical industry in 1901
}

\begin{abstract}
This article examines how the communication network of the Japanese pharmaceutical industry operated around the turn of the century to create spatial interactions across the national medicine market during a period of intense industrialization.

In 1901, pharmaceutical wholesalers in Osaka compiled The Telegraph Codebook of Pharmacies in Japan to facilitate national trade in medicine, although its use was restricted to only the 177 pharmacies that joined the Pharmaceutical Telegraph Communication Alliance. This alliance had close ties with wholesalers in Osaka and comprised national-level qualified chemists. The use of this communication network by telegraph enabled the integration and progression of the Japanese pharmaceutical market in the early $20^{\text {th }}$ century; however, pharmacies also began to build different and layered communication networks that corresponded to their respective business styles. Findings indicate that pharmacies used different communication networks of different spatia scales, thereby operating regional specialization and national integration networks simultaneously.

Keywords

Industrialization $\cdot$ regional formation $\cdot$ pharmaceutical industry $\bullet$ telegraph code $\cdot$ Japan $\cdot$ patent medicine

(C) University of Warsaw - Faculty of Geography and Regional Studies
\end{abstract}

Introduction

Past studies of historical geography and economic history, which focus primarily on England, have debated the difficulties of theorizing regional formation as a differentiated but integrated phenomenon within the evolving systems of modern capitalist accumulation (Gregory 1988, 2000; Hudson 1989; Langton 1988; Stobart 2009). While the national economy of England was becoming increasingly integrated thanks to new transport and telecommunication technologies, regional specialization was also making considerable progress during the industrialization period at the turn of the $20^{\text {th }}$ century. Most scholars agree that regional specialization and national integration were not dichotomous phenomena at that time, and instead emphasize that increasing regional specialization depended on concomitant processes of intra- and inter-regional integration (Gregory 1990).

Some previous research, however, does not clarify howand through whom-these two processes were accomplished; in this context, the role of human agencies, which linked production with markets and distribution in practice, is critical, because the prosperity of industrial regions was based on sales to mass markets. Focusing on the role of merchants and wholesalers, other recent studies examine how commercial communications created real spatial interactions across the industrializing economy of England in the late $18^{\text {th }}$ and early $19^{\text {th }}$ centuries (Stobart 2004; Popp 2009).

These features apply not only to England, the world's first industrializing nation, but also to a late-industrializing country such as Japan. In recent years, research about modern historical geography in Japan has undergone significant development in response to studies like those that focus on England, as
Takashi Amijima

School of History, Department of Historical Culture,

Bukkyo University, Kyoto, Japan.

e-mail: t-amijima@bukkyo-u.ac.jp

Received: 16 November 2018

Accepted: 11 February 2019

mentioned above. For example, taking a structuration approach similar to Giddens (1984) and Gregory (1981), Yamane $(2009,2016)$ explored the relationships between regional formation and individual human agencies, such as a statesman, a merchant, and a newspaper editor, by examining their spatial recognitions. In addition, Shimizu (2013) clarified the role of local wealth holders and entrepreneurs in developing the regional railway system in central Japan.

The role played by individual human agency, however, which helped to operate such networks in Japan has not yet been fully clarified. By examining the information network of pharmaceutical trade papers published in Osaka, the author clarified how the medicine market in Osaka was tied to the regional economies of various parts of Japan (Amijima 2015). To understand the actual conditions of spatial organization during the industrialization period in Japan, this article further examines the personal relationships and methods that enabled individual human agencies to operate commercial communication networks-such as the telegraph communication networks of Japanese pharmacies-to create spatial interactions among remote regions during the industrialization period.

The pharmaceutical industry in late $19^{\text {th }}$ and early $20^{\text {th }}$ century Japan faced rigid state control and various regulations with respect to health and welfare. This led to plentiful written sources about the behaviours of and relationships among pharmacies. In terms of methodology, this article draws on the contents of The Telegraph Codebook of Pharmacies in Japan, which was compiled in 1901 in Osaka. Focusing on pharmaceutical wholesalers who used the codebook, this article 


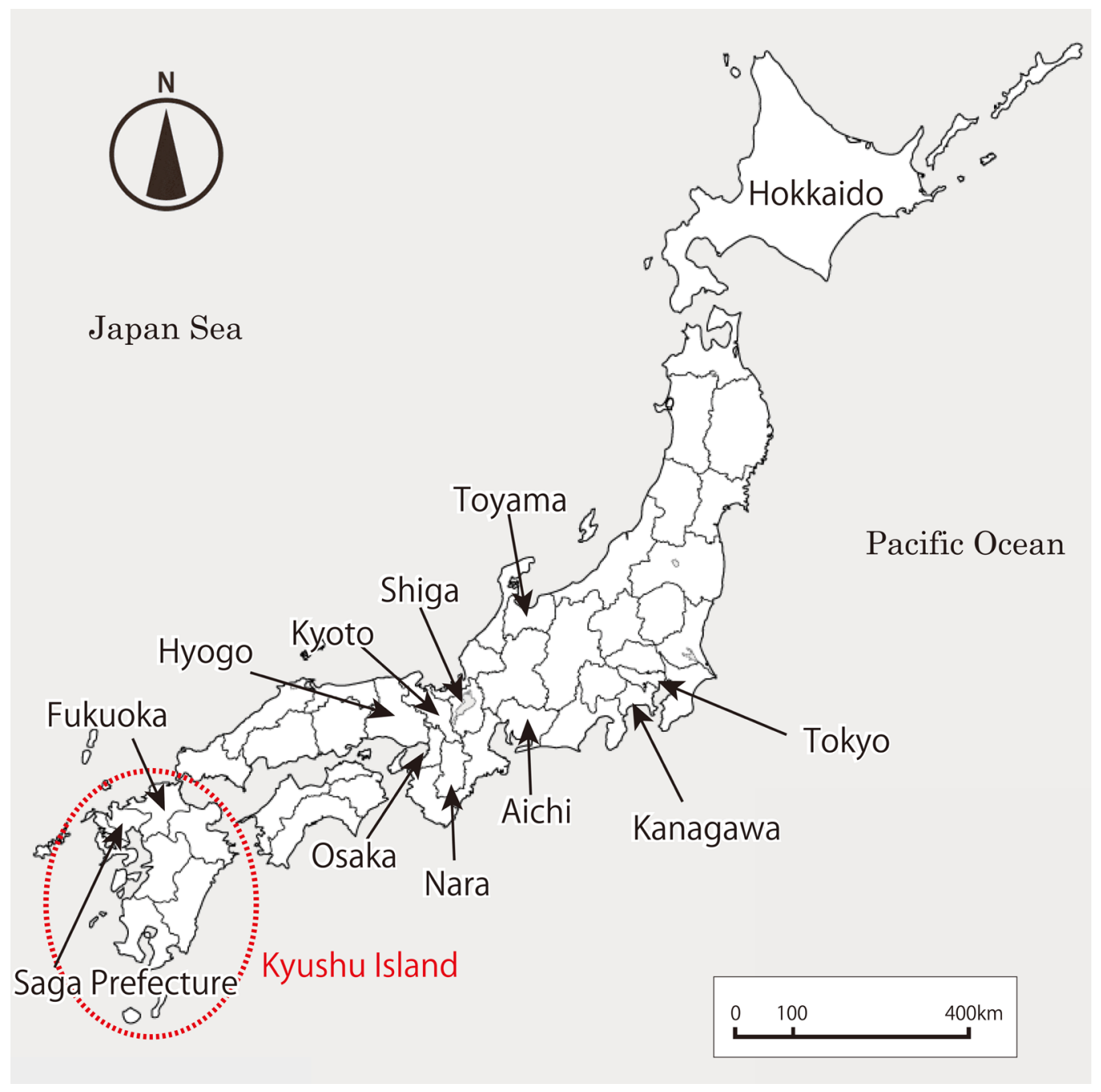

Figure 1. Study prefecture locations.

Source: author's own illustration.

explores their role in the telegraph communication network that linked regional formation with national markets and distribution systems. To reconstruct the relationships of these pharmaceutical wholesalers, this article uses a range of source materials such as pharmaceutical trade papers, trade directories, and biographical records of local pharmacies as supporting evidence.

The structure of this article is as follows. First, we verify and describe the situation of Japan's pharmaceutical industry in the late $19^{\text {th }}$ and early $20^{\text {th }}$ centuries; next, we outline the contents of The Telegraph Codebook of Pharmacies in Japan, followed by an analysis of the telegraph communication network of pharmacies in Japan during this time. Then we clarify some spatial characteristics of this network compared with the urban system in early $20^{\text {th }}$ century Japan. The final section discusses how individual human agencies helped operate this network of pharmacies to create spatial interactions between remote regions in late $19^{\text {th }}$ and early $20^{\text {th }}$ century Japan.

Pharmaceutical industries and telegraph communications in late $19^{\text {th }}$ and early $20^{\text {th }}$ century Japan

Pharmaceutical jurisprudence in Japan during the late $19^{\text {th }}$ and early $20^{\text {th }}$ centuries included two types of medicine: Kyokuhouhin, which was contained in the Japanese pharmacopoeia, and Baiyaku, or patent medicine. In the late $19^{\text {th }}$ century, Western chemical medicine was introduced into Japan, and it soon was considered an orthodox form of medicine. Following this, the national government established the Japanese pharmacopoeia in 1886 to regulate the properties and quality levels of medicines. Items selected for entry in this pharmacopoeia were mostly restricted to Western chemical medicines. Traditional pharmacies continued to produce patent or over-the-counter medicine, which was compounded according to the producer's own secret methods. The Japanese government did not endorse the medical virtues of patent medicine, but permitted their sale because of the high tax revenues gained (ed. the Japanese Society of History of Pharmacy 1995).

Figure 1 shows the locations of the prefectures referred to in this article. Osaka is in western Japan and is considered a historical centre of the national medicine market when Tokyo was the imperial capital city, and subsequently it developed as the new centre of the national medicine market in the late $19^{\text {th }}$ century (Amijima 2012). Shiga, Toyama, Nara, and Saga prefectures were traditionally famous as patent medicine production regions (ed. Toyama Prefecture 1987; ed. Compilation Committee of Pharmaceutical 


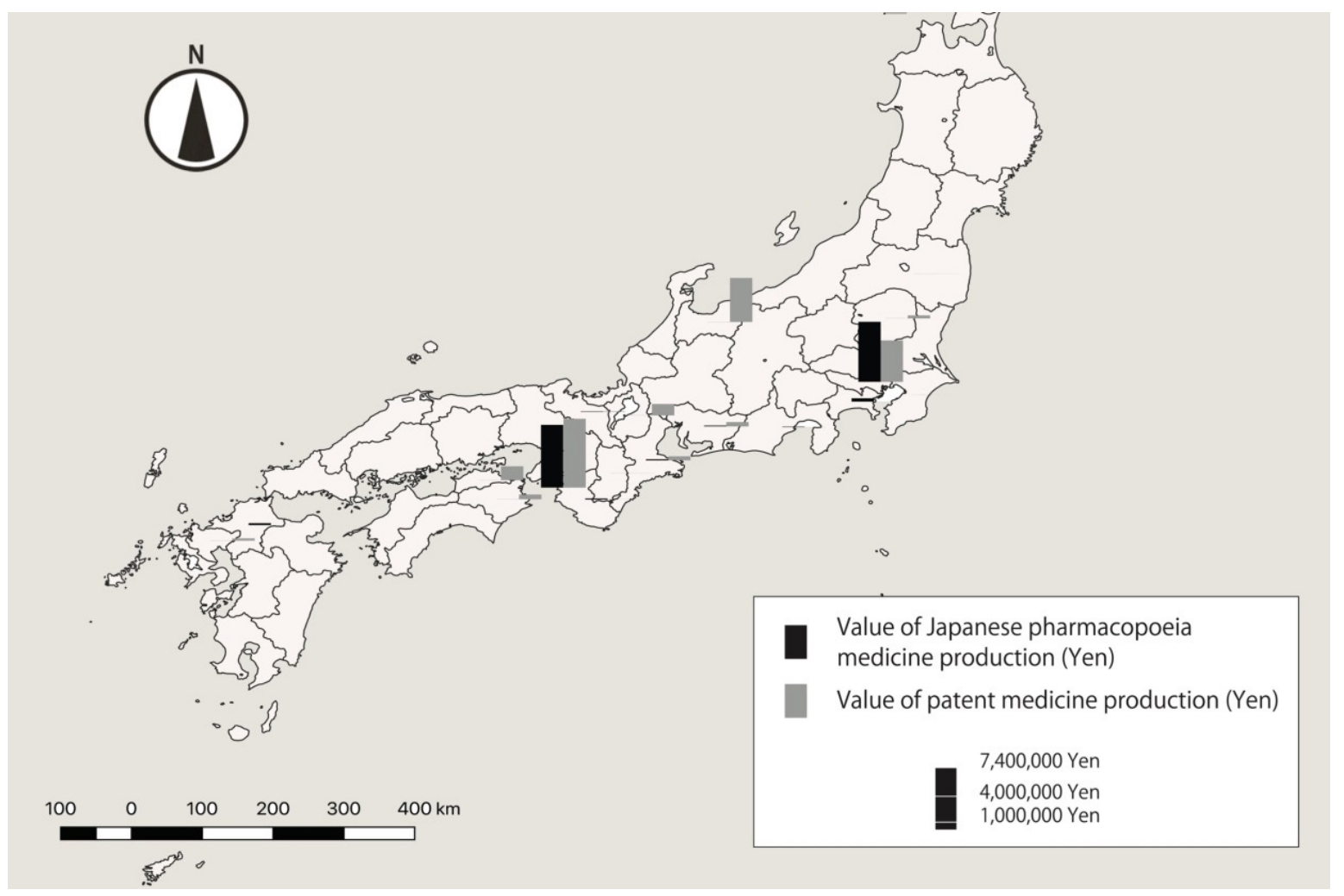

Figure 2. The production values of medicine in 1919 organized by prefecture. Source: Secretariat statistics division of the Ministry of Agriculture and Commerce (author's own illustration)

Industry in Nara Prefecture 1991). On Kyushu Island, Fukuoka was well known as the centre of the local markets for patent medicine.

Figure 2 shows the production value of medicine in 1919 organized by prefecture. As shown, the production of Japanese pharmacopoeia medicine was concentrated in the Osaka and Tokyo prefectures; however, the production of patent medicine shows a relatively decentralized spatial structure, as it was considered a "local" industry. The following analysis focuses on the production and distribution of patent medicines.

The first telegraph line in Japan was constructed between Tokyo and Yokohama (Kanagawa prefecture) in 1869, and was approximately $32 \mathrm{~km}$ in length. Since then, the Japanese government rapidly constructed the country's domestic telegraph lines by itself to protect domestic communication sovereignty from interference by foreign enterprises, such as the Great Northern Telegraph Company of Denmark, which had the concession of Japanese international telegraph lines (Itoh 2007). In 1874, the construction of the Japanese domestic main telegraph line was completed, which connected Hokkaido and Kyushu (Fujii 2005).

Figure 3 shows the distribution of telegraph stations organized by prefecture in 1901. There were 1,826 telegraph stations in Japan. Except for Hokkaido and Okinawa, which were under colonial rule in the late $19^{\text {th }}$ century, there were relatively few local differences in the number of telegraph stations. In the early $20^{\text {th }}$ century, telegraph stations spread not only in metropolises, such as Tokyo and Osaka, but also in provincial cities throughout Japan. Compared with other Asian countries' experiences such as China, Japan experienced rapid development of the domestic telegraph network with a few local differences, and this network was under the firm control of the Japanese government. By the 1890s, pharmacies began using this public network to promote long-distance business.
The Telegraph Codebook of Pharmacies in Japan

The Telegraph Codebook of Pharmacies in Japan was originally in the possession of Kabei Hatae, who ran a pharmaceutical wholesale business in Hakata Kuramotocho, Fukuoka Prefecture, from the Edo period. In 1965, these documents were donated to the Fukuoka prefectural library by Kaichiro Hatae, Kabei Hatae's son, and they remain there as part of "the Hatae Collection", with about 27,000 documents detailing Hatae's business management, as well as his biography, which is summarized below.

Kabei Hatae was born in 1864 in Hakata Higashi-cho. He was the largest pharmaceutical wholesaler in Fukuoka Prefecture in 1918 and dealt with Japanese pharmacopoeia medicines, patent medicines, and medical devices, among other items (Figure 4). He was a national-level qualified chemist and held various positions including councillor of the Hakata Board of Trade, and chairperson of the Fukuoka Prefectural Pharmaceutical Trade Association (Goto 1904b).

The Telegraph Codebook of Pharmacies in Japan was compiled by Ito Sentaro, who was a pharmaceutical wholesaler in Osaka and chairperson of the Osaka Druggist Wholesale and Brokerage Association. He mainly dealt in Japanese pharmacopoeia medicines (ed. Osaka Druggist Wholesale and Brokerage Association 1941). He compiled the codebook to ensure convenience and consistency in the communications among Japanese pharmacies remote from each other at that time. Use of the codebook was restricted to the 177 pharmaceutical wholesalers and pharmaceutical industries that joined what Sentaro called the Pharmaceutical Telegraph Communication Alliance. At the end of the codebook is a list of the alliance members.

The book contains 5,677 codes, sorted based on the Iroha order, which is the traditional ordering of Japanese syllabary, 


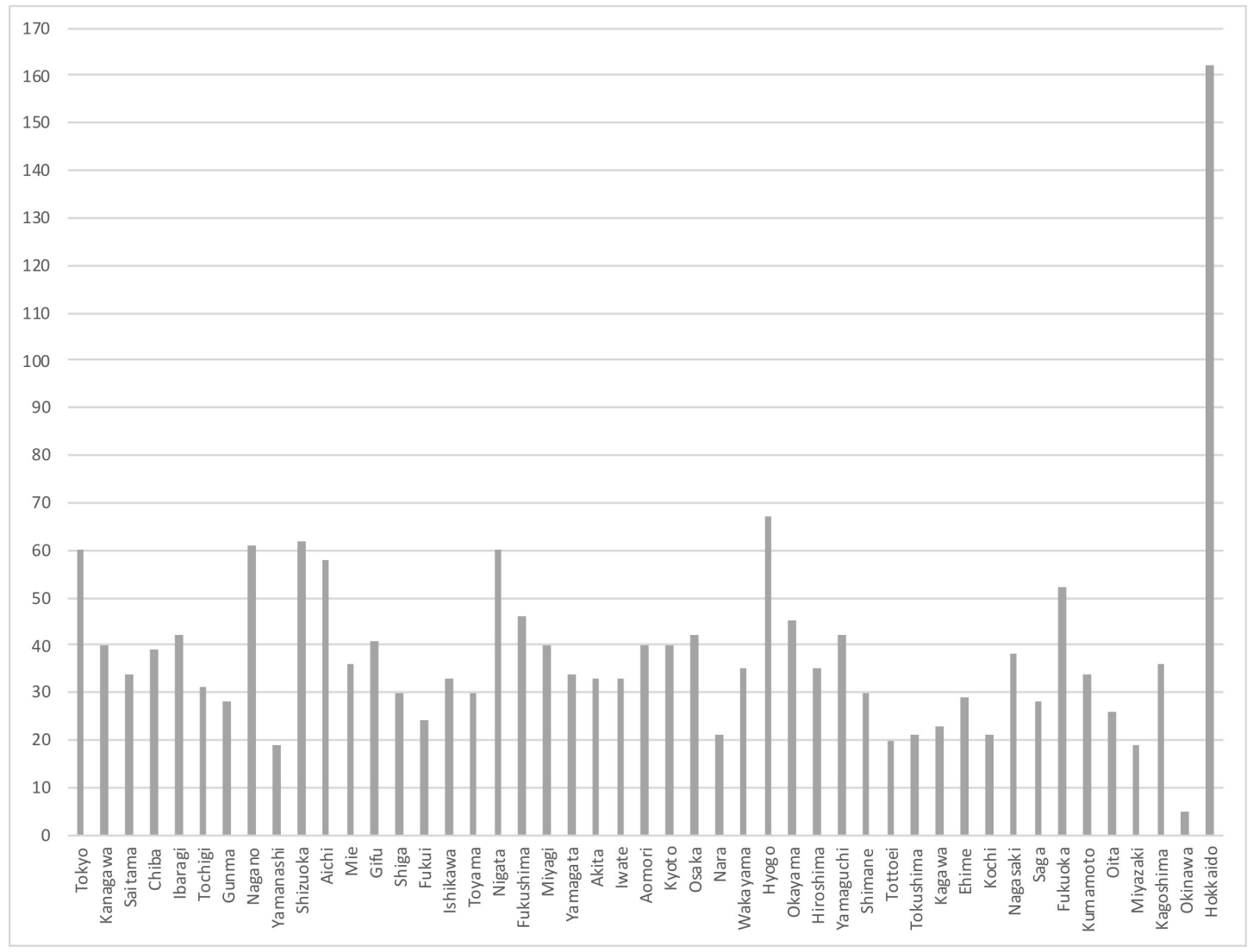

Figure 3. The distribution of telegraph stations in 1901 Japan.

Source: Naikakufu Tokeikyoku 1902, Statistical Yearbook of the Empire of Japan, 21st. (author's own illustration).

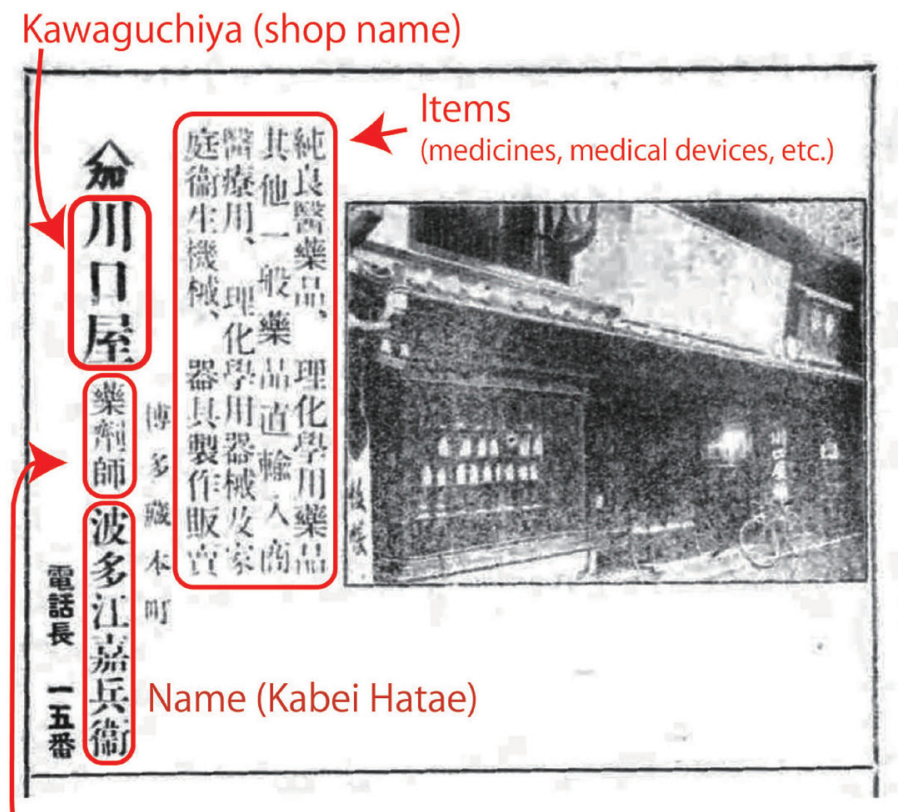

A Japanese qualified chemist

Figure 4. Advertisement for Kabei Hatae.

Source: Goto (1904a) with explanations added by the author. 


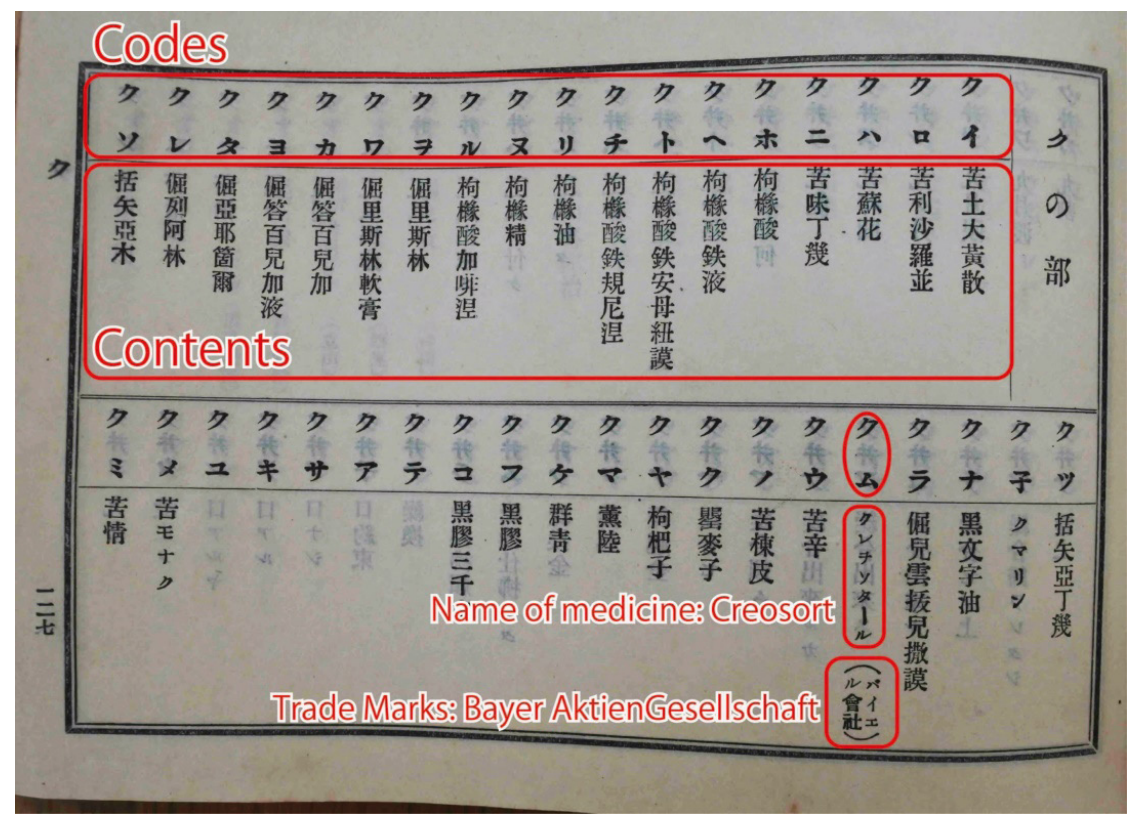

Figure 5. A page from The Telegraph Codebook of Pharmacies in Japan.

Source: The Telegraph Codebook of Pharmacies in Japan, p127 (Fukuoka prefectural library), with explanations added by the author

and then grouped according to subjects, such as combinations of medicines and categories of business terms. The codes consist of two or three Katakana, a Japanese system of syllabic writing mainly used for writing foreign words. The codes of patent medicines that bear the trademarks of manufacturers who joined the alliance are also included in the codebook (Figure 5).

The codebook contains 1,002 codes for generic medicines, 182 codes for the names of pharmacies that joined the alliance, 13 codes for the names of famous pharmacies that were not part of the alliance, 103 names of mail steamships, 211 patent medicines with trademarks, and 4,166 business terms. Out of the 1,002 generic medicine codes, almost all items belonged to Japanese pharmacopoeia medicine and Chinese herbal medicine. In the case of the 211 patent medicines with trademarks, 36 pharmacies encoded between 1 and 11 patent medicines each, and 16 pharmacies in local areas other than Osaka and Tokyo encoded 91 patent medicines.

The Spatial Structure of the Telegraph Communication Network of Pharmacies in Japan

Figure 6 shows the locational distribution of the 177 pharmacies that joined the Pharmaceutical Telegraph Communication Alliance, showing a concentration of these pharmacies in Osaka Prefecture, which contained 78 of the 177 member pharmacies. There were also smaller concentrations in Kanagawa Prefecture, which had 20 members, and in Tokyo Prefecture, which had 10 members.

Figure 6 also shows blank areas in the central and eastern parts of Japan, which contained no member pharmacies. It is assumed that the pharmacies in these areas had close ties with pharmacies in Tokyo, another centre of the national medicine market. Hence, it can be deduced that the members of the alliance formed a national medicine distribution network, excluding the Tokyo area, originating from wholesalers who were centralized in Osaka.

To consider the features of the Pharmaceutical Telegraph Communication Alliance's network, we compare its spatial structure with the Japanese urban system in the early $20^{\text {th }}$ century.
To clarify the historical transition of the Japanese urban system, Abe (1984) examined the distribution of big private enterprises' head offices in 1907 Japan. He took up joint stock corporations whose amount of stated capital was more than $¥ 500,000$ using Nihon Zenkoku Shokaisha Yakuinroku (Directory of Executive Board Members of Corporations in Japan) published by Shogyo Koshinsho. It is pointed out that the predominant feature of the Japanese urban system in the early $20^{\text {th }}$ century was that the number of offices in Tokyo was exceptionally large, and most head offices agglomerated in 6 major cities, including Tokyo, Yokohama (Kanagawa prefecture), Nagoya (Aichi prefecture), Osaka, Kyoto and Kobe (Hyogo prefecture) (Figure 7). These six cities were the most populous in early $20^{\text {th }}$ century Japan (ed. Tanabe1980).

In comparing Figures 6 and 7 , it could be pointed out that the spatial structure of the Telegraph Communication Network of Pharmacies had its centre in the western part of Japan and was geographically more distributed than the ordinary urban system in early $20^{\text {th }}$ century Japan. In Figure 6 , the most agglomerated area was not Tokyo but Osaka, and the numbers of the six big cities were not necessarily prominent. Compared with Figure 7, the numbers of Hyogo and Aichi were very low. On the other hand, we can observe a prominent agglomeration in Fukuoka.

Bias can also be seen in the information included on pharmacies and their patent medicines in the codebook; there are no codes for patent medicines prepared by the pharmacies in Toyama, Nara, and Saga prefectures, which were famous regions for production of patent medicines (Toyama Prefecture 1987; ed. Compilation Committee of Pharmaceutical Industry in Nara Prefecture 1991). Conversely, however, there were codes for 26 patent medicines made by 3 pharmacies in Fukuoka Prefecture, and 9 patent medicines made by 1 pharmacy in Shiga Prefecture.

Human agencies' impact on the network supporting the Telegraph Codebook of Pharmacies in Japan

To clarify the roles of individual human agencies in the telegraph communication network, we need to examine the pharmacies that dealt in patent medicines in Fukuoka and Shiga 


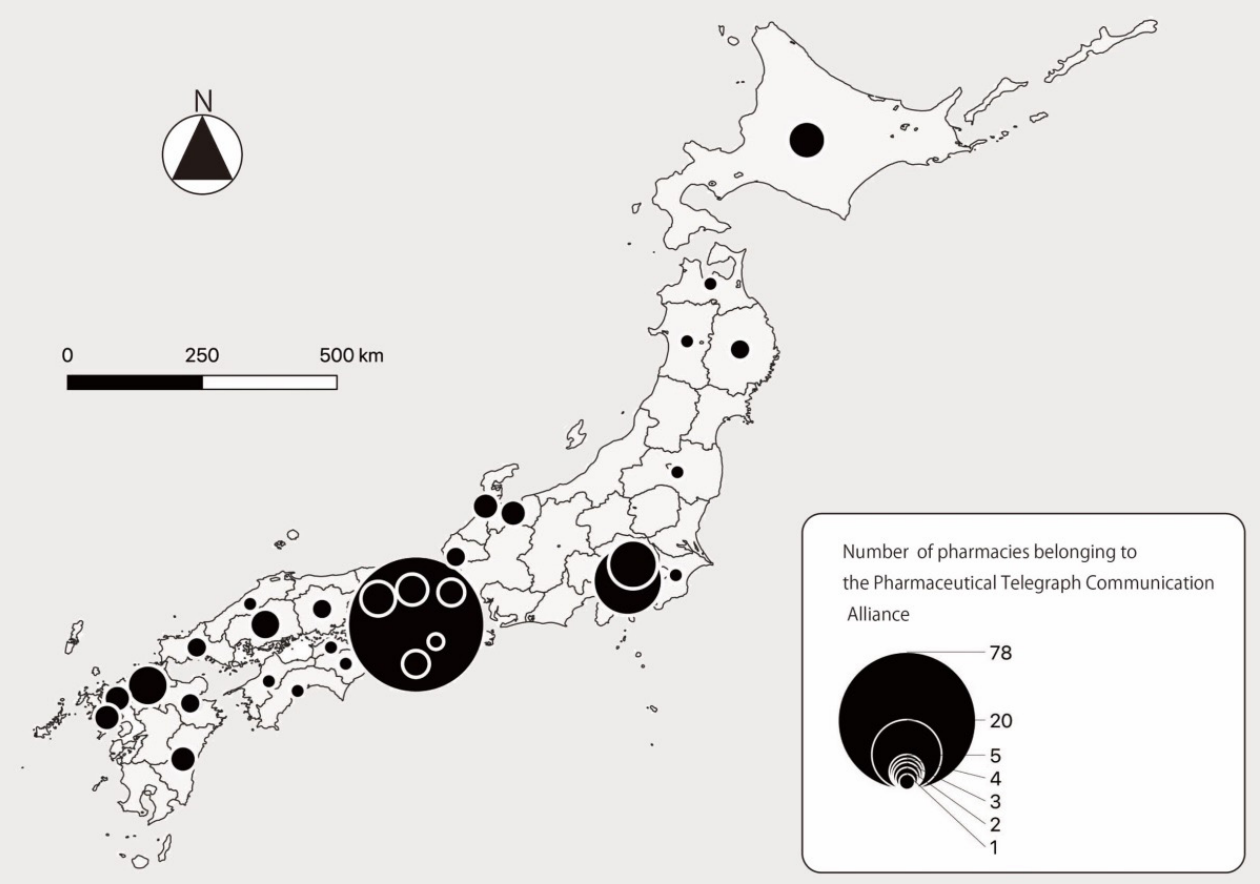

Figure 6. Locational distribution of pharmacies belonging to the Pharmaceutical Telegraph Communication Alliance (author's own illustration)

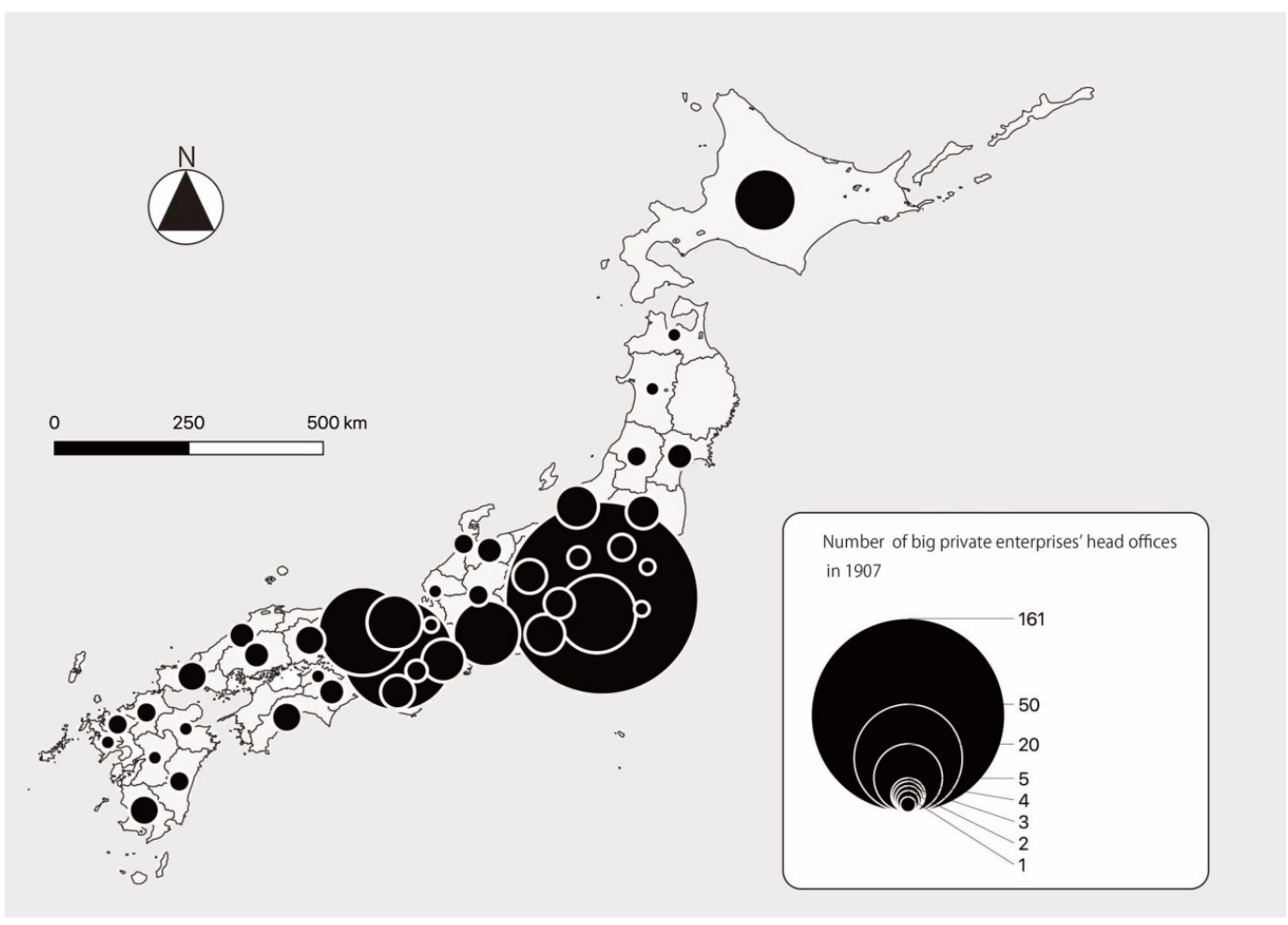

Figure 7. The distribution of big private enterprises' head offices in 1907 Japan

Source: Abe (1984: 44-48), (author's own illustration) 
prefectures. For example, the codes for Kabei Hatae's patent medicines are representative examples of patent medicines made in Fukuoka Prefecture. There are six codes for items that hold Hatae's trademark, mostly including honey and related products, which were different from actual patent medicine: Beeswax, Hypo-Beeswax, Spring Honey, Summer Honey, Autumn Honey, and Red Honey.

Some descriptions of Hatae's business plan are included in biographical records titled "The biographies of pharmacies in Kyushu region", which were published by the Kyushu Pharmaceutical Trade Paper Company in 1904: "Every year he ships honey and beeswax to Osaka and its neighbourhoods. He won a prize in the $5^{\text {th }}$ National Industrial Exhibition held at Osaka, in 1903. ... He lays up stock of pharmacopeia medicine from wholesalers in Osaka and sells them to customers in Fukuoka, Nagasaki, and Oita prefecture. ... now he has plans to expand his business to the Japanese national market" (Goto 1904b, pp. 24-27). This description shows that while Hatae continued his main occupation as a wholesale business in the Kyushu region, he planned to sell his stock to remote areas without mediation from wholesalers in Osaka. We assume that using the codebook provided him with the opportunity to expand his business to a national market.

The codes for pharmacist, and national-level qualified chemist, Gohei Fujioka, include patent medicines made in Oumi Hino district, Shiga prefecture. His shop was established in the late $16^{\text {th }}$ century (Motomura 2011). There are nine codes for items with Fujioka's trademark: Heburin-san (powder for the common cold), Jitsubo-san (powder for female disorders), Shouniyakuo Kannou-gan (general-purpose pill for children), Noubyou-tan (medicated paste for brain diseases), Bannou-gan (general-purpose pill), Manbyou Kannou-gan (general-purpose pill), Furidashi Goshaku-san (general-purpose powder), Yu-tan Enreishi (Nourishing tonic made of bear's gall), and Semennennsan (Santonin powder).

Among these nine patent medicines is Manbyou Kannou-gan, which was a famous patent created by Genzo Shono, who was a patent medicine producer in Oumi Hino district, Shiga Prefecture, during the late $17^{\text {th }}$ century. He was the first chairperson of the association of Shiga prefectural patent medicine pharmacies (Motomura 2008). Both Fujioka and Shono sold patent medicines under the same name. Since the method of manufacturing a patent medicine was usually strictly confidential, it is hard to imagine that these two medicines were similar even though they shared the same name. This indicates that pharmacies could not purchase Shono's Manbyou Kannou-gan through the network of this codebook.

Pharmacies and medicine wholesalers that were not affiliated with the alliance had several common features. First, membership in the alliance was restricted only to pharmacies that had close ties with Japanese pharmacopeia medicine wholesalers in Osaka. As such, the name Yoshichiro Takeuchi is not included in the codebook. Takeuchi founded the Kyushu Pharmaceutical Trade Paper Company and created networks among pharmacies around Fukuoka Prefecture in the Kyushu region and participated in the establishment of Tokuseikai, which was a national association of patent medicine suppliers established in 1887. He had close ties with Shitaro Tani, the first chairperson of Tokuseikai and a famous patent medicine wholesaler in late $19^{\text {th }}$ century Osaka (Goto 1904a; Yoshida 1960). Tani was not included in the codebook either.

Second, most members of the alliance were nationallevel qualified chemists. While we can find Gohei Fujioka in the codebook, Genzou Shono is not included. Shono and Fujioka established the Oumi-Hino Pharmaceutical Industry Company, which was established by local patent medicine pharmacies in
Shiga Prefecture in 1914. Both Shono and Fujioka ran branch shops in Osaka (Motomura 2008); however, only Fujioka belonged to the alliance.

This leads us to infer that the network of the alliance was different from the networks of the mainstream patent medicine pharmacies throughout Japan. Shono visited Fukuoka Prefecture in July 1914 for the inspection of pharmacies in the Kyushu region. According to the Kyushu Pharmaceutical Trade Paper of July 25, 1914, "Genzo Shono, the chairperson of the association of Shiga prefectural patent medicine pharmacies, stayed in Fukuoka for ten days. He had talks with Kabei Hatae and showed intentions of expanding Shiga prefectural patent medicine pharmacies' business to Fukuoka prefecture, which was a promising market for patent medicines" (Kyushu Pharmaceutical Trade Paper 1914, p. 6). We may also infer that pharmacies that handled patent medicine tried to create new connections with pharmacies in other regions to sell their medicine directly to these new partners.

\section{Conclusions}

This article examined how the communication network of Japanese pharmaceutical industries operated around the turn of the century to create spatial interactions across the national medicine market during the industrialization period. First, it introduced features that would become widespread among the pharmaceutical industry in late $19^{\text {th }}$ and early $20^{\text {th }}$ century Japan and emphasized the importance of patent medicines as a local industry. Second, The Telegraph Codebook of Pharmacies in Japan showed the locational distribution of pharmacies that used this book. Third, it examined the spatial structure of this telegraph communication network of pharmacies and showed that this network had its centre in the western part of Japan and was geographically more distributed than the ordinary urban system in early $20^{\text {th }}$ century Japan. Fourth, this article analysed the role of individual human agencies in this telegraph communication network by focusing on pharmacies in Fukuoka and Shiga prefecture.

From the above examination of the reorganization of the Japanese space economy, a national medicine distribution network of pharmacies can be seen among those who joined the Pharmaceutical Telegraph Communication Alliance. While membership in the alliance was restricted to pharmacies with close ties to Japanese pharmacopeia medicine wholesalers in Osaka and comprised national-level qualified chemists, in late $19^{\text {th }}$ and early $20^{\text {th }}$ century Japan, other pharmacies began to build layered, national communication networks that corresponded to their respective business styles. In addition to this, as my previous article showed (Amijima 2015), subscribers of the nationally published pharmaceutical trade paper, Sourakushinbun (The Japan Druggist), had interconnective networks among Japanese pharmacopeia medicine wholesalers and patent medicine wholesalers.

These findings indicate that pharmacies used several different communication networks of unique spatial scales depending on their purpose, thereby operating regional specialization and national integration networks simultaneously. To sell Japanese pharmacopeia medicine purchased from pharmaceutical wholesalers in Osaka, pharmacies mainly used intra-regional networks; conversely, when they tried to expand their businesses to remote regions, they relied on national or inter-regional networks.

\section{Acknowledgements}

This paper was originally prepared for presentation to the $17^{\text {th }}$ International Conference of Historical Geographers. I am especially grateful to Wiesława Duży, Martin Christopher Kotecki and Hiroshi Kawaguchi for offering insightful comments. This 
study was supported by a Grant-in-Aid for Scientific Research (Grant Number 16K16954) from the Japan Society for the Promotion of Science. We would like to thank Editage (www. editage.jp) for English language editing.
The author holds all copyrights of the figures.

\section{References}

Abe, K 1984, 'Head and branch offices of big private enterprises in major cities of Japan', Geographical Review of Japan, vol.57 (Ser. B), no.1, pp. 43-67.

Amijima, T 2012, 'Continuing agglomeration of the pharmaceutical trade in the modern era: the case of Dosho-machi town, Osaka, Japan, 1868-1923', Japanese Journal of Human Geography, vol. 64, no.2, pp. 123-141.

Amijima, T 2015, 'Urban industrialisation and information network: analysis of pharmaceutical trade papers in Osaka, Japan, 1907-1911', Program Book of the 16th International Conference of Historical Geographers. Available from: <http://www.ichg2015.org/wp-content/uploads/ICHG-2015Programme-Book.pdf>. [10 December 2018].

Compilation Committee of the History of Pharmaceutical Industry in Nara Prefecture (ed.) 1991, The history of pharmaceutical industry in Nara prefecture: the overview, The Federation of Pharmaceutical Industry in Nara Prefecture, Nara.

Fujii, N 2005, Communications and regional society, Nihon Keizai Hyoronsha Ltd., Tokyo.

Giddens, A 1984, The construction of society, Polity Press, Cambridge.

Goto, K 1904a, The biographies of pharmacies in Kyushu region (Kyushu yakugyouka retsuden) volume II, Kyushu Pharmaceutical Trade Paper Company (Kyushu Yakuhosha), Fukuoka.

Goto, K 1904b, The biographies of pharmacies in Kyushu region (Kyushu yakugyouka retsuden) volume III, Kyushu Pharmaceutical Trade Paper Company (Kyushu Yakuhosha), Fukuoka.

Gregory, D 1981, 'Human agency and human geography', Transactions of the Institute of British Geographers, vol. 6, no. 1 , pp. 1-18.

Gregory, D 1988, 'The production of regions in England's industrial revolution', Journal of Historical Geography, vol. 14, no. 1, pp. 50-58.

Gregory, D 1990, "A new and differing face in many places': three geographies of industrialization' in An historical geography of England and Wales [second edition], eds RA Dodgson \& RA Butlin, Academic Press, San Diego, pp. 351-399.

Gregory, D 2000, 'Industrial revolution' in The dictionary of human geography 4th edition, eds RJ Johnston, D Gregory, G Pratt \& M Watts, Wiley, Blackwell, Oxford, pp. 385-388.

Hudson, P 1989 'The regional perspective', in Regions and industries: perspectives on the industrial revolution, ed. $\mathrm{P}$ Hudson, Cambridge University Press, Cambridge, pp.5-38.

Ito, S 1901, The Telegraph Code Book of Pharmacies in Japan (Yakugyoukadoumei Denshin Angouchou), Ito Sentaro, Osaka.

Itoh, E 2007, 'The Danish monopoly on telegraph in Japan: a case study of an unequal communication system in the far east', Keio Communication Review, no.29, pp. 85-105.

The Japanese Society of History of Pharmacy (ed.) 1995, History of pharmaceutical industry in Japan (Nihon iyakuhin sangyoushi), Pharmaceutical daily report company (Yakujinippousha), Tokyo.

Kyushu Pharmaceutical Trade Paper 1914, 'Inspectors visiting Fukuoka', Kyushu Pharmaceutical Trade Paper.
Langton, J 1988, 'The production of regions in England's industrial revolution: a response', Journal of Historical Geography, vol. 14, no. 2, pp. 170-174.

Motomura, K 2008, 'The role played by the Ohmi merchants in the development of the Hino drug industry: the Shono Genzo family in modern Japan', Fukuoka University Review of Commercial Sciences, vol. 53, no. 2, pp. 189-215.

Motomura, K 2011, 'Entrepreneurship of Ohmi Merchants: A case of the family of Fujioka Gohei', Fukuoka University Review of Commercial Sciences, vol. 55, no. 4, pp. 467-485.

Osaka Druggist Wholesale and Brokerage Association (ed.) 1941. The history of drug sellers in Osaka Volume IV, Osaka Druggist Wholesale and Brokerage Association, Osaka.

Popp, A 2009, 'From town to town: how commercial travel connected manufacturers and markets during the industrial revolution', Journal of Historical Geography, vol. 35, no.4, pp. 642-667.

Shimizu, K 2013 Regional formation of Mino area in modern times (Kindai Mino no chiikikeisei), Kokonshoin, Tokyo.

Stobart, J 2004, The first industrial region: north-west England c.170060, Manchester University Press, Manchester.

Stobart, J 2009, 'Industrial revolution' in The dictionary of human geography 5th edition, eds RJ. Johnston, D Gregory, G Pratt \& M Watts, Wiley, Wiley-Blackwell, Malden, Mass, pp. 378380.

Tanabe, K (ed.) 1980, Japanese urban system: a geographical study, Kokonshoin, Tokyo.

Toyama prefecture (ed.) 1987, The history of pharmaceutical industry in Toyama prefecture: the overview, Toyama Prefecture, Toyama.

Yamane, H 2009 'The spatial recognitions of Toshimichi Okubo and the formation of regions in Modern Japan', Japanese Journal of Human Geography, vol. 61, no.6, pp. 23-41.

Yamane, H 2016 'Development of important ports and sea areas in the territorial expansion of modern Japan', Geographical Review of Japan Series B, vol. 88 no. 2, pp. 96-110.

Yoshida, J 1960 'The epitome of Japanese pharmaceutical industrial history (Nihon yakushi ryaku)', Annual proceedings of Gifu Pharmaceutical University, vol. 10, pp. 1-39. 